\title{
PHILOSOPHY OF MONEY AS THE BASIS FOR FORMING A MODERN SUCCESSFUL MAN
}

\section{Borinshtein Ye. R.}

\section{INTRODUCTION}

In the last decade, the importance of money in the practice of economic life of Ukrainian society has increased. This is due to the transition to market mechanisms for regulating the economy, which makes the role of money more significant, since money-mediated relationships are becoming more widespread. The planned economy and the command methods of managing the economy are almost replaced by market mechanisms based on money, on the dominance of monetary interest in the activities of economic entities, monetary motives and incentives. They are crucial at all levels of economic activity. But if the economic consequences of the development of monetary relations are investigated and analyzed to one degree or another, that creates the basis for their forecasting and management, then insufficient attention is paid to the social results of changing the role of money in society. There is still very little socio-philosophical analysis of the role of money in society, not studied sociocultural processes accompanying the changing role of money in society, while the consideration of such issues is extremely relevant for the entire world community.

Today, the value of money is undergoing a period of intense transformation. Thus, developed countries are characterized by the widespread distribution of monetary relations, and although, of course, we are not talking about the rejection of the use of monetary, market mechanisms, but recently there has been an increasing departure from purely economic development priorities towards greater attention to the problems of achieving sociocultural goals addressing issues of socio-humanitarian development.

Big changes are associated with the position of money in the international arena, in relations between states. This is due to the widespread development of virtualization and globalization processes in the modern world, which leads not only to an increase in the value 
of world currencies, but also to the emergence of qualitatively new phenomena related to the formation of a single world economy (for example, the creation of a single European currency), the emergence of various kinds of cryptocurrencies (one of the most popular today is Bitcoin), transforming money space.

Today, the role, functions and value of money have begun the path of radical renewal. All this requires a new understanding and study for further use in specific activities to manage social processes, to develop optimal policies. Understanding the phenomenon of money and predicting possible ways of its transformation as a universally valid socio-philosophical, and, consequently, cultural universal is our essential task.

In the study of the philosophy of money it is necessary to be aware that money is at the same time a special commodity, a universal equivalent of the cost of other goods, services and a universal product of the human society acting as universal equivalent, also serving as a mean of circulation, metabolism, payment, measurement of value and accumulation of wealth.

According to the most common version, the Russian word "money" came from the Turkic "tenge" or from the Khazar "Tamga" - "brand", "seal". Tenge (danek in Arab countries; dangkh in Persia; tanka, tangka or tanga in India, Ceylon, Tibet and Nepal; tanga or tenga in the Khiva and Kokand khanates, in the Bukhara emirate) - initially small silver, and then copper coin in the countries of the East. In ancient Greece and Persia, these coins were called danaka and the Greek obol, which meant the tetrahedral rod, when iron rods were the means of money circulation. In "Walking Over Three Seas" by Athanasius Nikitin (XV century), Indian and Chinese money are called tenka ${ }^{1}$.

Historically, the exact time of the appearance of money is not determined. However, for the first time to hold the silver payment mentioned in the cuneiform inscriptions around 2500 b.c. ${ }^{2}$. After that, metals began to serve as a means of payment. Later, this was reflected in the appearance of coins.

\footnotetext{
1 Деньги - происхождение слова, функции, виды и формы... URL: https://WhatisMoney.ru/money/.htm

2 Деньги - это... Деньги: сущность, виды и функции. URL: https://fb.ru>article/196739/dengi---eto...suschnost-vid/htm
} 
It should be noted that the development of commodity circulation, when surpluses of goods appeared, was a hint for the appearance of money.

We are also interested in, first of all, that money is a social phenomenon, affects a person's worldview, helps him realize the importance of a systematic approach, a more accurate assessment of a particular product, this or that service. The advent of money has transformed the consciousness of man, and with the modernization of money circulation our consciousness is being modernized. That is why it is important to study the philosophy of money.

\section{The existential foundations of the philosophy of money}

The philosophy of money as a scientific discipline is a philosophical analysis of the systemic influence of the logic of money, monetary relations on the world-spiritual world of man and society.

A holistic picture of money can be created on the basis of their analysis not only as a medium of circulation, but also as a goal. As a means of circulation, money contributed to the development of trade, the acceleration and expansion of the movement of goods and services, the formation of state and interstate economic relations. As a goal, money had a huge impact on human development, attitude to work. That is, money has updated not only changes in the world of things and in the world of people, in the inner world of a person, his interests, ideals and aspirations, moral criteria. They significantly changed the system of human values hanks to this, money went beyond its natural (traditional) functions as the equivalent of goods and services, expanding the scope of its functioning.

A holistic picture of money can be created on the basis of their analysis not only as a medium of circulation, but also as a goal. As a means of circulation, money contributed to the development of trade, the acceleration and expansion of the movement of goods and services, the formation of state and interstate economic relations. As a goal, money had a huge impact on human development, attitude to work. That is, money actualized not only changes in the world of things and in the world of people, in the inner world of a person, his interests, ideals and aspirations, moral criteria. They significantly changed the system of human values. Thanks to this, money went 
beyond its natural (traditional) functions as the equivalent of goods and services, expanding the scope of its functioning.

The accumulation of money, from the point of view of the values of a liberal society, is a useful step, since it ensures the development of the economy and ensures the prosperity of the state. Money in society can form the basis of the foundation of individual freedom. Money is at the same time a measure of a person's self-realization. Money is of particular importance in a corrupt society. In such a society, the functions and meaning of money are deformed and hypertrophied, and the value of a person is defined as its purchasing power (a person can as much as he is able to buy). This society appears before a person as a product, because everything can be bought in it (law, morality, social thought, justice, and even life). It is clear that a person is not able to sell the law, honor, homeland, morality, but is able to sell himself. He can trade only himself, his feelings, faith, conscience, provided that all this has acquired for her the attributes of a product, has lost its primary, true meaning. That is, a person can sell not only his work, his services, but also his spirituality, turn it into a product. At the level of the spirit, a person does not sell, but sells, that is, becomes a commodity.

Consequently, the morality and immorality of money depends on the person, but money can be a measure of morality and immorality of a person.

A holistic picture of the philosophy of money as a scientific discipline can be compiled on the basis of the analysis of money not only as a medium of exchange, but also as a goal. As a medium of exchange, money contributed to the development of trade, the acceleration and expansion of the movement of goods and services, and the formation of public economic relations. As a goal of exchanging money, they had a huge impact on the development of man himself, his goal-setting activity, his attitude to work. They changed the value orientation of a person and his idea of ethical standards.

The different role of money, as a means and as a goal, was already considered by Aristotle in his doctrine of the state, and served as a theoretical foundation for distinguishing between the concepts of "economy" as the art of acquiring useful goods and "chrematistics" 
as a way of enrichment. The first he considered necessary, appropriate to nature and having its borders, and the second - not corresponding to nature and without boundaries ${ }^{3}$.

The further course of history showed that both roles of money are necessary and expedient, and, moreover, they represent the unity of opposites, and their inherent internal contradiction serves as a source of social development.

From such positions, the essence of money was analyzed by K. Marx, revealing the laws of their transformation into capital ${ }^{4}$. About the increasing power of money over people's actions when they become a goal, G. Simmel wrote in his Philosophy of Money 5 .

The historical mission of money is not only to "facilitate trade" and not only to develop a "market economy" aimed at making a profit, but also to form an "economic person" with its special value attitudes - to form what will later be called "spirit" capitalism. Money brought changes not only to the "world of things" and not only to the "world of people," they played a role in changing the inner world of a person, his interests, ideals, aspirations, and moral criteria. Money has changed the human value system, placing itself at the center as a universal economic value.

Money - it is worth, but what does it consist? To talk about the real value of money can be only when they exist in the form of precious metals, essentially real money. But the transition to other forms of money (coins, banknotes), which have only a nominal value, turns them into a sign, symbol, into an information carrier. But, nevertheless, they remain a real value and due to this they can act as a means and purpose of exchange. Their value does not come from their material form, but from the content of the social process that they mediate with their movement and make it possible.

It must be understood that money is a thing that has its own special form of movement from one person to another and expresses a certain way of communication. A thing that, regardless of its material or symbolic form, serves as a tool for social interaction of people

\footnotetext{
${ }^{3}$ Аристотель. Политика. Афинская полития. М.: Мысль. 1997. 458 с.

${ }_{5}^{4}$ Маркс Карл. Капитал. М.: АСТ. 2019. 544 с.

5 Simmel Georg. Philosophy of money. - Boston: Routledge \& Kegan Paul.
} 1978. 803 p. 
through exchange. This is the "source of the enormous value of money for society." follows:

So, the scientific essence of the philosophy of money is as

1. Money has significantly changed the system of human values, therefore, studying the philosophy of money makes it possible to see the possibilities of the influence of money on a person and the construction of a new "economic person" that will be competitive in modern society.

2. Money in the community can form the basis of the foundation of freedom s personality. Accordingly, the philosophy of money can offer a faster way from slavery to maximum freedom of human existence in the world.

3. The philosophy of money plays a significant role in understanding the differences between the material and the spiritual in the modern world.

4. The philosophy of money helps to understand the meaning of such categories as morality and value in modern society.

It's no secret that money plays a significant role in our lives. Every day of our existence is connected with them, every step we take. It is generally recognized that their presence is due to purely economic necessity. And, probably, that is precisely why all the studies carried out in this direction imply a purely economic or neareconomic character.

Money is often perceived as a forced element of reality, due to the need for economic leverage to regulate social life. However, it does not at all follow from this that their influence on humans is completely exhausted by the sphere of the economy. Whether we like it or not, we are obliged to state the fact that the monetary problem has not just burst into our lives and daily reminds of itself; it has a significant impact on the formation of morality, the hierarchy of values; finally, it has a direct psychological and philosophical impact on a person and society.

Money is able to satisfy a person's household needs, serve as a source of comfort and material well-being. Moreover, the presence of financial surpluses is associated with the process of realization of a certain social and subject freedom of a person. All this does not go beyond the traditional functions of money, that is, those very functions 
that are defined by their understanding as the equivalent of goods and services. The alarming symptom is different, namely, the artificial expansion of the functions of money, in the expansion of their natural "competence". Due to this, a serious analysis of the visible relationship between the presence of financial surpluses, on the one hand, and the spiritual being of the individual, his true freedom, the possibility of creative realization, and social recognition, on the other, becomes relevant.

If the internal spiritual resources are exhausted (or experienced as such), a hidden inferiority complex arises. All hopes are turned to public authority; it is he who must justify the existence of man, prove to him his full value and spiritual integrity. It is at this stage of the spiritual crisis that the idea of a purely mechanistic selfrealization arises. An unshakable faith in "public opinion" as the highest measure of values provokes unsatisfied self-awareness on pseudo-decisions. Spiritual emptiness can be compensated by another possibility - the possibility of recognition through economic exclusivity.

According to the values of a liberal society, according to which a significant part of humanity continues to live to this day, the ability to increase capital is regarded not only as a very useful social step that ensures the development of the economy and the prosperity of the state. The concentration of capital around a person is also associated in the social sciences with productive energy, willpower and the eccentricity of the individual. It is in this way that modern man, overcoming his own passivity and weakness, fundamentally changes his being, rebuilds the world around himself, subordinates it to his goal and makes him live by his own rules. There is an image of a certain superman, a standard of well-being. In modern society, a person's financial elevation is increasingly seen as a public recognition of his significance and exclusivity, as the highest and most complete realization of his intellectual abilities.

An essential point in the perception of money as a force of human capabilities lies in the idea of equality, common to all the rules of the game. Just as any person is able to create his own body, make his muscles supple and sculpted, and thereby rise above the crowd, everyone has a real chance to create himself through the accumulation of capital. Raised in the rank of official ideology, the idea of equality 
and equal conditions for achieving material well-being impresses the consciousness of the layman. In this case, money acts as another equivalent- the equivalent of I, my abilities and my value. The higher this equivalent is calculated digitally, the larger the I. The idea of equality, embodied in money, means equal opportunity for everyone to achieve social inequality. At the same time, the achievement of designated inequality is experienced as an exceptional spiritual, and its non-implementation - as a spiritual inferiority, which is not true based on the essence of human existence.

Speaking about the "philosophy of money", I mean the worldview influence that the logic of monetary relations exerts on the worldview and behavior of a person.

Money determines the quantitative boundaries of the possible in the actions of people. By means of money, quantitative proportions of exchange are established, based on the principle of equivalence of alienated and appropriated goods. However, money simultaneously expresses the qualitative limitlessness of what is possible in the actions of people. Due to their universal value, they act as an unconditional incentive and motive for any type of activity, including anti-human activity, they make attractive any work, including directed against a person, they turn into a purchase and sale item that should not be such.

Money fills the human will in all its manifestations with material power and simultaneously creates a social mechanism for its realization (market), but they are indifferent to what this will is aimed at. This is the realm of the mind.

Modern science has huge achievements in the development of cash flow management methods, but many questions of the theory of money remain unanswered. We must seek the essence of money not in the mechanisms of market functioning, but in the laws of the development of society. Money is a tool for the development of civilizations and its result. Therefore, they require philosophical reflection.

Therefore, the philosophy of money, as a scientific discipline, is the way to accumulate knowledge of the objective need for money and the laws of development as a social phenomenon, which allows you to identify their impact on the "world of things", "human world" and "the world of the individual". 
The philosophy of money can make a definite contribution to nurturing the ability of society to remember that "the measure of all things" should always be a person. That is, we return all the time to classical ancient philosophy: "Man is the center of the whole existence of the world."

Uniqueness is the uniqueness of a person, and his ability to be different from the rest. The uniqueness of the human person lies in a rational existence in comparison with animals, the ability to think and reason, make decisions and improve oneself. The uniqueness of a personality is revealed at all levels of its existence: social, cultural, biological, physiological, psychological, and so on. Is it possible to talk about personality in proportion to the cost of human life and society? From the point of view of philosophy, one can speak, but it is impossible to measure. From the point of view of the philosophy of money, such opportunities are provided.

For the philosophy of money, it is essential not only to understand money as capital, but also to compare money with personal capital, which means knowledge of the employee's skills and professional abilities, as well as his individual, including moral, characteristics.

In itself, without a human personality, money capital is more symbolic than material. Therefore, understanding the essence of the metaphysics of money is significant.

The metaphysics of money is an essential understanding of money. In each of the options, money is the carrier of a temporary connection of the past - present - future, and thus provides a certain causal relationship, although the value-moral nature of these relations is significantly different. It's one thing: investing free money in banks, property, antiques, jewelry - in this case they symbolize wealth, belonging to a particular social group, are used as a means of creating a prestigious image, social attractiveness, as a characteristic of a successful person. Savings made by virtue of caring for one's old age and supporting children have another social meaning. They testify to the personal responsibility of people, the connection of generations, the lack of consumer hype.

It is necessary to take into account the duality nature of money. On the one hand, money as a universal substitute for commodity values allows time-bound relationships to occur, stimulates imaginary consumption, and on the other hand, not being values in themselves 
(except for gold money), they are subject to cost fluctuations, gain weight and significance depending on social the conditions in which they operate: they are affected by inflation, the financial policy of the state, carrying out monetary reform and controlling the monetary mass, weak protection of the value of money itself by the law, by political problematic moments and so on.

The function of money as a means of payment is expanding (this process is especially stimulated by the introduction of electronic systems). This changes the distribution of the significance of functions: the function of the medium of circulation is absorbed more and more money is transferred from the pockets to the accounts, people satisfy their needs without touching the monetary substance.

\section{The role of the substance and the case of money in the formation of a modern successful person}

Substance (from Lat. substantia - essence) - the essence of the world, which always remains constant and unchanged. The concept of substance is connected with the question of the root cause of the world. The problem of substance in an explicit form was posed by the ancient Greek philosopher Aristotle. Today, substance is usually represented as a synonym for material, material.

Accident (from lat. accidere - fall from above) - a concept introduced for the first time by Aristotle to characterize what expresses the way manifestation of the substance of a thing. That is, a substance is a philosophical concept that denotes a temporary, transient, inconsequential, variable, random property of a thing (as opposed to an essential, substantial). Money is a temporary phenomenon. The main thing is the amenities they provide.

The essence of money is manifested in their internal content and is expressed in the unity of all the diverse and contradictory forms of being of money. There are at least 4 approaches on the essence of money in the development of mankind: value, representation, state and rational.

The cost approach connects the ability of money to perform its functions with their intrinsic value. Say, any product can be exchanged for gold coins (today simply for money) because the gold contained in them has the same value as the exchanged goods. 
The representative approach that has developed in Soviet (and later Ukrainian) society since the $70 \mathrm{~s}$ is a modification of the value approach. The ability of money to perform its functions by its supporters is also associated with value, but with an important caveat: the central value is not given to the value of the money itself, but to the value of the goods they represent. This can be explained by the following analogy: the financial obligations of the debtor are guaranteed not by the value of the paper on which it is written, but by the goods pledged to them (apartment, car, and so on).

The state approach, especially developed in the framework of the German school of the 20th century, proceeded from the fact that money is endowed with its own special properties as a result of a volitional act of the state. That is, the state not only creates money, but also prescribes them a payment force.

A functional approach is most common in modern society. He is characterized by his attitude to money as a specific tool, spontaneously developed (or, more precisely, selected among many alternatives) by the market economy to solve the problems of commodity circulation. Only money instruments that were able to best perform the functions dictated by the market were able to hold on to the economy as money. Hence, money can be anything that people recognize for money and fulfill their functions.

1. Pricing of goods. In a market economy, they (prices) are formed on the basis of the value of the goods themselves, taking into account demand, supply, and competition. Thanks to these indicators, manufacturers can reduce product prices. Money also plays a large role in the process of money circulation, while the functions of money as a means of payment and circulation are revealed. The buyer controls the prices and quality in the market, buying goods, thereby forcing manufacturers to constantly improve the quality of products and reduce prices for them.

2. Estimation of profit and loss. Having studied the essence and functions of money, the state and private enterprise are able to determine the total production costs for each product, the total cost, and also obtain production results based on the prices of each type of product, volume and profit.

3. Possibility of accounting. The wise use of knowledge of the essence, functions and role of money, makes it possible not only to 
use money, but also to coordinate money income, expenses, which as a result leads to an economical expenditure of funds. It is important to use a stable currency, since the impact of inflation on it is not great.

4. Streamlining public relations. Money (currency) reflects the economic, social, cultural and psychological relations in society.

5. Persistence. Money retains its value in contrast to goods.

6. Portability. Concentration of high cost in a small volume.

7. Divisibility-connectivity. When dividing, the equivalent must not lose its value. When combining money, the value must be preserved.

8. Homogeneity. Any part of the cash equivalent must be equal to its other part. With fur, sausage, fish, other goods this is not.

The essence of money, in my opinion, is revealed, first of all, in five functions:

- Cost measures

- Means of circulation

- Means of payment

- Savings and Savings

- World money

A measure of value is formed during the formation of prices, it determines the value of the goods, which is measured in money (i.e., equating goods with each other). Thus, receive quantitative commensuration. The monetary measurement of value is price. It depends on several conditions:

- production conditions;

- terms of exchange. In order for prices to be comparable, they must be scaled down.

As a measure of value, money can act as counting, acting in the form of numerical values. Counting money is used to express prices, accounting and analysis, maintaining accounts of participants in economic life.

Means of circulation. The monetary expression of the value of goods does not mean its realization. An exchange must occur. Money - intermediaries in the exchange from the beginning of the transaction to its completion. In the period when trade dominated, money basically acted as a medium of circulation; after the emergence of credit and the development of the economy, the function of the 
means of payment comes to the fore, which includes the function of the medium of circulation and transforms into the function of the means of payment. This is facilitated by the use of plastic cards and other electronic payment tools that allow you to pay by transferring from a bank account, as well as making wholesale and retail purchases.

Means of payment - the time of payment does not coincide with the time of payment, goods are sold in credits, with deferred payment.

Savings - cash reserve (account balances, foreign exchange reserves). Money performing the function of accumulation is involved in the process of formation, distribution, redistribution of national income, and the formation of savings of the population.

World money is used in international payments.

In the modern developed economy, there are four functions of money - a measure of value, means of accumulation and means of settlement, world money, and the medium of circulation remains in very small amounts.

Understanding the concrete and the abstract value of money in the philosophy of money begins, in my opinion, with the work of George Simmel's "Philosophy of money", which was dedicated to the disclosure of the role, nature and essence of money. It was he who, through his work, formed the understanding that money is a thing that has its own special form of movement from one person to another and expresses a certain way of communication. A thing that, regardless of its material or symbolic form, serves as a tool for social interaction of people through exchange. This is the source of the enormous value of money for society.

Money are a tool, but it is easy to become an end in itself, relegating the true values to the level of funds. Money and abstract formal reasoning are the most important achievements of human civilization. They determine the whole power of modern life and its complexity. Money can create and destroy the spiritual essence of man.

The specificity of money is reflected in the understanding of capital. Money is capital. The category "capital" (from lat. capitalis main) is more than ambiguous (I will give the most popular understandings) : 1) wealth, stock of goods and services; 2) wealth (property, money) used to produce more wealth; 3) the aggregate of 
assets used for future profit; 4) private wealth or value, which as a result of exploitation of wage labor brings surplus value (according to Karl Marx); 5) resources that are extracted from consumption in the present (accumulated) and used for profit in the future (according to the Austrian economic school: Karl Menger, Eugen von BoehmBaverk, Friedrich von Wieser, Ludwig von Mises, Benjamin Anderson, Friedrich von Hayek, Murray Rothbard, and others).

Understanding capital as one of the central concepts of the philosophy of money leads us to a very interesting concretization of its varieties.

Cultural capital (from the lat. capitalis - chief and from the Lat. cultura - cultivation, upbringing, education, development, respect) the accumulation of wealth in the form of knowledge and ideas, turned into an integral part of the personality, which is the foundation of her life and position in society. Introduced into scientific knowledge by the French scientist Pierre Bourdieu ${ }^{6}$.

Social capital (from lat. capitalis - main and from lat. socialis public) - social ties that can act as resources for achieving economic, political, social, cultural and other goals. For the first time, the term was used by the American scientist Lida Judson Hanifan ${ }^{7}$. It was introduced into the scientific circulation by the French scientist Pierre Bourdieu.

Sociocultural capital (from lat. capitalis - main, lat. socialis public and from lat. cultura- cultivation, upbringing, education, development, veneration), based on my work on the basics of sociocultural, I would interpret it as a phenomenon of social life, based on the accumulated intellectual wealth of society, society, a group of individuals, a person and expressed in tangible and intangible forms of existence and development of subjects of sociocultural activity.

${ }^{6}$ Bourdieu Pierre. Ökonomisches Kapital, kulturelles Kapital, soziales Kaputal, in: Kreckel, Reinhard (ed.) Soziale Ungleichheiten (Soziale Welt, Sonderheft 2). Güttingen: Otto Schwartz \& Co. 1983. P. 183-198.

${ }^{7}$ Hanifan L. J. Ed. (1913). District Supervision: West Virginia and Oregon as Examples. National Society for the Study of Education, Twelfth Yearbook. Chicago, University of Chicago Press. 
The human capital (from lat. capitalis - main and from praslav. * Čel - - member of a clan or family and praslav. *věkb- - health, strength) can be understood as:

1) the totality of knowledge, skills used to meet the needs of man and society as a whole;

2) a special capital in the form of intellectual abilities and practical skills obtained in the process of education and human activities.

Our capital is a quality of life, not money.

Under the quality of life. (From the English quality of life: standard of living, quality of life, quality of life, quality of life) can mean: 1) category, which is expressing satisfaction with the quality of the material and spiritual needs of people (the quality of food, quality clothing, housing comfort, the quality of health care, education, the service sector, the environment, the structure and level of leisure, the degree of satisfaction of communication needs, knowledge, creative work, resettlement structure, etc.); 2) systems of indicators characterizing the degree of implementation of people's life strategies, satisfaction of their material and spiritual needs; 3) the subjective evaluations at the satisfaction of material and spiritual needs of people (satisfaction with financial situation, food, health, work, the level of freedom in society, their rights, and so on); 4) the perception of the individual s of their position in life in the context of culture and value systems in which they live and in relation to their goals, expectations, standards and concerns (according to the World Health Organization $(\mathrm{WHO}))^{8}$.

Therefore, the most valuable thing is the quality of life that we create for ourselves and those around us.

Money as the most liquid asset with a fixed nominal value must be inherent in universality. Money comes in the form of universal direct exchange on all other products. As a result, all the goods, participating in the circulation, find their final consumer. Universality is a property of unhindered performance of obligations in relation to all entities offering goods and services in the market. Therefore, money must be universally recognized. The universality of money is provided by:

\footnotetext{
${ }^{8}$ Всемирная организация здравоохранения URL:https//www.who.int/
} 
- by law. Corresponding normative acts (constitution, law on the monetary system, etc.) determine the legal tender in the territory of a state or group of states, united in a monetary union;

- public confidence in money. The usefulness of money as an economic good is maintained even with a decrease in their purchasing power, if the predictability of the value of money and their ability to fulfill their functions in the future remain. If public confidence in money falls, then no regulatory documents will force people to make savings in the form of monetary assets. People will prefer less liquid but more reliable assets (for example, will be buying gold or land, etc.).

Uniformity should be inherent in money - standardization (interchangeability). This property is inherent in money, as a rule, due to its uniformity and lack of individual characteristics. As a universal tool, they allow free exchange for any good. Interchangeability facilitates transactions, that is, it allows you to organize the accumulation of values in non-cash form of current accounts, transfer between them is as simple transfer.

Money should be distinguished by transportability (i.e., be convenient for transportation), recognizability and suitability for storage, without losing its value, and should also have portability (i.e. high cost per unit weight). We can say that the transition from one form of money to another, a change in the types of money is associated with a person's desire to make money more convenient for use in economic circulation, to reduce transaction costs when making various kinds of economic transactions (hence the emergence of cryptocurrencies to exclude banks as an unnecessary intermediary).

An important property of money is its protection from fakes, which makes it easier for the state to combat counterfeiting. The possibility of forgery of cash, or "hacking" on the means of cashless payments and electronic money, leads to the appearance of counterfeit money that violates abutment ability of monetary circulation and causes distrust of people with money. The Internet is a good way to steal money in developing countries. In modern society, not only improved the security features of banknotes themselves, but also about are found large-scale campaign to educate people about security features newly issued banknotes in various denominations. 
Complicated and advanced banking technologies, the introduction of which special attention is paid to the protection of the banks systems against hacking.

F particular importance in today's increasingly complex world, in my opinion, is such a feature of money as its transcendence. Transcendence as a category occurred, and from Latin transcendens "crosses", "superior", "going beyond the limits." In general, it means that which is fundamentally inaccessible to empirical knowledge or is not based on experience. The term "transcendental" was most fully disclosed in the philosophy of Immanuel Kant, where it was used to describe things-in-themselves, existing independently of consciousness and acting on our senses, while remaining fundamentally unknowable, both in practice and in theory ${ }^{9}$.

But it is important to understand that some things-in-themselves are still available a priori knowledge: for example, space and time, ideas of God, goodness and beauty, logical categories. That is, transcendental objects are, figuratively speaking, "predefined by default" in our mind.

Money is inherently transcendental. They are in the wallet, and we always imagine how many of them we have in total, including in goods (apartment, car, cottage, etc.). That is, the money that we take into account in the ratio that we need today. Money is in the realm of impression, experience- this is where their transcendence lies.

At the same time, money is a phantom. Money is not a thing - it is only a conditional symbol for the exchange of things. In other words, the value does not consist in the money itself (this is just paper), but in those things that we can exchange for this money. It seems to us that we are rich when there are many of them, and that we are poor when they are few.

Paradoxically, a person does not need the money to feel rich and owning the whole world (remember the monks in the monasteries). At the same time, a man with millions of banknotes can feel poor, because, no matter how much he did not bank notes, he does not cease to be afraid of the world without them, and is in constant fear of their loss.

\footnotetext{
${ }^{9}$ Кант Иммануил. Критика чистого разума. Мн.: Литература. 1998. 960 с.
} 
The main thing is the ability to create your own value. Monetary wealth is always temporary (for example, money depreciates due to inflation). But the intrinsic value of a person as a person who can attract money into his life, on the contrary, will not depreciate with time, but only increase if it strengthens this ability in itself.

I think that the sum of our skills is our life. Life - a movement, and that is constantly moving, will be developed. What matters is not money, but cash flow. Cash flow is the core of any financial system. A man cannot live without regard to cost, and cannot exist without earnings. But earnings are not only money. Whenever income exceeds your expenses, a person becomes richer every day. Whenever your expenses exceed your income, you are poorer. Therefore, a wise man, to cultivate their own asset values will always keep your own money flow (knowledge, skills, and so on) in a positive balance.

The goal of true wealth lies in the constant movement, or in other words, multiplication, only then it lives and grows.

The harmony of gaining wealth consists in gaining your own value. That is why many very rich people continue their work only by modernizing its components, although they have more than enough money to retire and live comfortably for many years. They like what they do, because for them it is not work, but life itself. They do not earn money; they develop their own value - this is their life. Therefore, their monetary wealth is also constantly growing.

Therefore, it is necessary to become a valuable, not wealthy person. So, the ability to create values in this world is important, and then wealth, wealth and success will invariably come to you. Each activity should increase the professionalism of a person and the joy of engaging in their own chosen business. And in this case, a person should be considered successful. A modern successful person is formed under the influence of many factors, and the philosophy of money has one of the most important influences on the development of a modern successful person.

\section{CONCLUSIONS}

The problem of money fascinates almost everyone, since it to one degree or another affects all levels of human existence. 
Speaking about the prerogative of the analysis of the stated problem, even in the narrow sense, we are already causing interest. Of course, you can analyze money as a sociocultural phenomenon, which is one of the most important human inventions. But a much more significant is a systematic analysis of money in a scientific context, for which the philosophy of money as a scientific discipline is ideally suited.

From this we single out the following scientific significance of the philosophy of money: studying the philosophy of money makes it possible to see the possibilities of the influence of money on a person and the construction of a new "economic person" that will be competitive in modern society; the philosophy of money can offer a faster way from slavery to maximum freedom of human existence in the world; the philosophy of money helps to understand the material and spiritual essence of the world, the meaning of categories such as morality and value in modern society.

The specific essence of money is displayed in the concept of "capital". But already the categories of "social capital", "cultural capital", "sociocultural capital", "human capital" provide an opportunity to explore and understand not only the specific component, but also the abstract meaning of the essence of money.

The rationality-the irrationality of money and money circulation has become closer to humanity after Immanuel Kant spoke of transcendence. Money is in the realm of impression, experience - this is where their transcendence lies. At the same time, money is a phantom. Money is not a thing - it is only a conditional symbol for the exchange of things.

A successful modern man, by its very nature and nature, is impossible if he does not represent the possibilities of using money and its equivalent, which is constantly being transformed with a transforming world.

\section{SUMMARY}

The article discusses the basic essential foundations of the philosophy of money, the influence of the philosophy of money on human development, the role of the philosophy of money in the formation of a modern successful person. It is shown that in the essence of money philosophy manifests itself in the terms of 
philosophical analysis, the system influences the logic of money, monetary relations in the world vision and spiritual world of the individual and society, helps to understand the essence of such categories as the morality and value in today's society, reveals the influence of money in the "world of things", "human world "and" the world of the individual". The role of substance and incidence of money in the formation of a modern successful person is revealed. It has been clarified that the substance and incidences of money help to understand the essential nature of man. The manifestation of the concrete essence of money in the concept of "capital" is revealed. The relationship between social and cultural capital is shown. Based on the identified relationships, the definition of the category of "sociocultural capital" is given for the first time, by which I understand the phenomenon of social life, based on the accumulated intellectual wealth of society, society, a group of individuals, a person and expressed in material and intangible forms of existence and development of subjects of sociocultural activity. The role of transcendence for understanding and, in the future, the development of specific criteria of the essence of a modern successful person is highlighted.

\section{REFERENCES}

1. Деньги - происхождение слова, функции, виды и формы... URL: https://WhatisMoney.ru/money/.htm

2. Деньги - это...Деньги: сущность, виды и функции. URL: https://fb.ru/article/196739/dengi---eto...suschnost-vidyi...htm.

3. Аристотель. Политика. Афинская полития. М.: Мысль. 1997. $458 \mathrm{c}$.

4. Маркс Карл. Капитал. М.: АСТ. 2019. 544 с.

5. Simmel Georg. Philosophy of money. - Boston: Routledge \& Kegan Paul. 1978. 803 p.

6. Bourdieu Pierre. Ökonomisches Kapital, kulturelles Kapital, soziales Kaputal, in: Kreckel, Reinhard (ed.) Soziale Ungleichheiten (Soziale Welt, Sonderheft 2). Güttingen: Otto Schwartz \& Co. 1983. P. 183-198.

7. Hanifan L. J. Ed. (1913). District Supervision: West Virginia and Oregon as Examples. National Society for the Study of Education, Twelfth Yearbook. Chicago, University of Chicago Press. 
8. Всемирная организация здравоохранения URL: https://www.who.int/

9. Кант Иммануил. Критика чистого разума. Мн.: Литература. 1998. 960 с.

Information about the author: Borinshtein Ye. R., Doctor of Philosophy, Professor, Head of the Department of Philosophy, Sociology, and Management of Sociocultural Activites, South Ukrainian National Pedagogical University named after K. D. Ushynsky 26, Staroportofrankivska str., Odesa, 65020, Ukraine 